\title{
Medium optimization of production of xylanase by solid state fermentation from Brevibacillus borstelensis - MTCC 9874 isolated from soil sample of eastern Nepal
}

\author{
Uttam Budhathoki $^{1 *}$, Panna Thapa ${ }^{1}$ and Ellaiah Poluri ${ }^{2}$ \\ ${ }^{1}$ Department of Pharmacy, Kathmandu University, Dhulikhel, Nepal; GPO box 6250 (Kathmandu). \\ ${ }^{2}$ Department of Pharmaceutical Sciences, Andhra University, Visakhapatnam, India. \\ E-mail: uttam@ku.edu.np
}

Received 3 March 2010; received in revised form 28 December 2010; accepted 28 December 2010

\begin{abstract}
The main aim of this study was to optimize production medium in solid state fermentation for production of xylanase using Brevibacillus borstelensis MTCC 9874. The organism was isolated from Morang district of Nepal and it was grown for $96 \mathrm{~h}$ in five different mineral salt solutions (MMS) with rice husk and MSS-1 was selected as a medium for further study based on xylanolytic activity measured using DNS method. Plackett Burman design (Minitab 15.1) was done with six variables viz. dipotassium hydrogen phosphate, rice husk, sodium chloride, magnesium sulphate, sodium carbonate and calcium chloride. The result showed that dipotassium hydrogen phosphate and rice husk were significant factors for xylanase production (> 95\% confidence levels). Full factorial Centre composite design (CCD) was used to optimize the two significant factors. Response surface and contour plot were used to locate the optimal value of the two factors. There was $279.88 \%$ increase in xylanolytic activity after optimization of the medium. Study of effect of temperature on xylanolytic activity showed that maximum xylanolytic activity $(6.58 \pm 1.1 \mathrm{IU} / \mathrm{mL})$ was found at $60{ }^{\circ} \mathrm{C}$. Optimum $\mathrm{pH}$ was found to be 7.6 (Xylanolytic activity $=6.81 \pm 2.32 \mathrm{IU} / \mathrm{mL}$ ). Thermal stability study showed that the enzyme has a good stability at $60{ }^{\circ} \mathrm{C}(95.62 \%)$. Lineweaver - Burk plot showed that the enzyme has $\mathrm{V}_{\max }$ and $\mathrm{K}_{\mathrm{m}}$ values $0.1075 \mu \mathrm{g} / \mathrm{mL}$.min and $1427.63 \mu \mathrm{g} / \mathrm{mL}$ respectively.
\end{abstract}

Keywords: Xylanase, Plackett-Burman design, Response surface methodology, DNS method solid state fermentation

\section{INTRODUCTION}

Xylan is the most abundant non-cellulosic polysaccharide in hard wood (20-35\%) and soft wood (8\%), which constitutes approximately one third of all renewable organic carbon sources on earth (Asha Poorna and Prema, 2007). It is composed of a backbone chain of $\beta$ 1,4-linked xylosyl residues and short side chains of arabinosyl, glucoronosyl and acetyl residues (Kalogeris, $2000)$. Its enzymatic hydrolysis requires endo- $\beta-1,4-$ xylanase $(\beta-1,4-D$-xylan xylanohydrolase, EC 3.2.1.8) that cleaves glycosidic bonds to produce xylooligosaccharides and $\beta-1,4-D$-xylosidase ( $\beta-1,4-x y l o s i d e$ xylohydrolase, EC 3.2.1.37), responsible for the final breakdown of small xylooligosaccharides into xylose (Nascimento et al., 2002).

The cost of enzymes is one of the main factors determining the economics of a process. Reducing the costs of enzyme production by optimizing the fermentation medium is the basic research for industrial application (Ghanem, 2000). Several statistical designs have been used to optimize the medium which has several advantages over "Change-in-one-factor-at-a-time" method. In order to make the enzyme applications more cost effective at industrial level, its production using low cost substrates such as agro-wastes has been recommended and use of the agro-wastes has been possible by solid-state fermentation (SSF), which is closer to natural system and has proved to be more efficient in producing certain enzymes and metabolites (Asha Poorna and Prema, 2007).

Xylan-degrading enzymes have many important practical applications in various industrial processes, including the modification of cereal-based foodstuffs, improving the digestibility of animal feedstocks and delignification of paper pulp. Eco-friendly applications in paper/paper product manufacture and recycling, in textile manufacture, in baking, in the release of aroma and antioxidant molecules, and in the production of biopharmaceuticals, which are targeted at both selective and extensive modification of xylans, have provided an increased impetus to identify and obtain new xylanases with different specificities and properties (Ryan et al., 2003).

The objective of this study was to optimize medium for production of xylanase by solid state fermentation (SSF) and its purification. In order to improve characterized enzyme production, 'change-one-factor-ata-time" was replaced by Plackett-Burman design (PBD) followed by Response surface methodology (RSM) because of drawback such as unreliable results and inaccurate conclusion, expensive and time-consuming for large number of variables (Kuhad et al., 1998). In order to know the industrial potential of xylanase from this organism, the enzyme was purified and characterized. 


\section{MATERIALS AND METHODS}

\section{Microorganism}

All the isolates (202) were subjected to xylanase production tests by primary screening using xylan agar plate and congo red (Cordeiro et al., 2002). Among them, 9 isolates showed xylanolytic activity ratio more than 3 and were subjected to secondary screening by submerged fermentation. Among nine isolates, Brevibacillus borstelensis MTCC 9874 showed maximum xylanolytic activity. It was isolated from Eastern Sugar Mills, Amadeva, Morang district, Eastern Nepal. Its characterization was done using 16s rRNA analysis at Institute of Microbial Technology (IMTECH), Chandigadh,
India. Isolates were maintained at $4-8^{\circ} \mathrm{C}$ on half nutrient agar slants.

\section{Substrates in SSF}

Rice husk, rice straw and wheat straw were taken as substrates separately for SSF. Rice and wheat straws were cut into small pieces and were kept in hot air oven at $60 \pm 10^{\circ} \mathrm{C}$ for an hour before use.

\section{Mineral salt solutions}

Five mineral salt solutions with following contents were used for selection of a mineral salt solution (Table 1) (Virupakshi et al., 2005).

Table 1: Different mineral salt solution composition used for selection of moisturizing agent

\begin{tabular}{cccccc}
\hline $\begin{array}{c}\text { Mineral salt solution } \\
\text { (MSS) }\end{array}$ & $\begin{array}{c}\mathrm{K}_{2} \mathrm{HPO}_{4} \\
(\mathrm{~g} / \mathrm{L})\end{array}$ & $\begin{array}{c}\mathrm{NaCl} \\
(\mathrm{g} / \mathrm{L})\end{array}$ & $\begin{array}{c}\mathrm{MgSO} \cdot 7 \mathrm{H}_{2} \mathrm{O} \\
(\mathrm{g} / \mathrm{L})\end{array}$ & $\begin{array}{c}\mathrm{CaCl}_{2} \\
(\mathrm{~g} / \mathrm{L})\end{array}$ & $\begin{array}{c}\mathrm{Na}_{2} \mathrm{CO}_{3} \\
(\mathrm{~g} / \mathrm{L})\end{array}$ \\
\hline MSS-1 & 6 & 6 & 0.4 & 0.2 & 10 \\
MSS-2 & 4 & 4 & 0.2 & 0.1 & 8 \\
MSS-3 & 2 & 1 & 0.1 & 0.05 & 5 \\
MSS-4 & 2 & 1 & 0.05 & 0.03 & 5 \\
MSS-5 & 1 & 0.5 & 0.05 & 0.02 & 5 \\
\hline
\end{tabular}

\section{Solid state fermentation}

Each dried substrate $(10 \mathrm{~g})$ was kept in Erlenmeyer flask $(250 \mathrm{~mL})$ and mineral salt solution $(20 \mathrm{~mL})$ of different composition were kept in each flask. All the flasks were sterilized at $105 \mathrm{~kg} / \mathrm{cm}^{2}$ for $45 \mathrm{~min}$. Sodium carbonate solution was sterilized separately and was added into the sterilized flask under aseptic condition. Inoculum (48 h old) of Brevibacillus borstelensis ( $4 \mathrm{~mL}$ ) was added aseptically into the flask followed by shaking gently. The flasks were kept in incubator humidified with sterile water $\left(55^{\circ} \mathrm{C}\right)$ for $96 \mathrm{~h}$ and the best among the five was selected based on xylanase activity assay measured using DNS method.

\section{Xylanase activity assay}

Xylanase activity was assayed using hydrolyzing xylan from birchwood (Sigma, USA). Liberated reducing sugars were quantified by dinitrosalicylic acid (DNS) method (Miller, 1959). One $\mathrm{IU} / \mathrm{mL}$ is expressed as 1 microgram of xylose formed per $\mathrm{mL}$ per min. Each experiment was done in triplicate.

\section{Experimental Design}

\section{Plackett-Burman design}

Plackett Burman experimental design with six variables viz. dipotassium hydrogen phosphate, sodium chloride, magnesium sulphate, calcium chloride, calcium carbonate and rice husk in solid state fermentation (SSF) was performed using Minitab 15.1 to screen the nutrients that were significantly affecting xylanase production. The six factors were screened in fifty three experimental run. The enzyme activity assay was carried out in triplicate and average of it is reported as response/enzyme activity (Table 2).

Each factor was examined at two levels: -1 for low level and +1 for high level and centre point were run to evaluate the linear and curvature effects of the variables based on PBD (Armstrong NA, 2006). The design is based on the first-order polynomial model:

$$
Y=\beta_{0}+\Sigma \beta_{i} x_{i}
$$

Where $Y$ is the response (enzyme activity), $\beta_{0}$ is the model intercept, $\beta_{i}$ is the linear coefficient and $x_{i}$ is the level of the independent variables. This model does not describe interaction among variables and is used to screen the significant factors that influence response/enzyme activity (Wejse et al., 2003).

The factors significant at $95 \%$ level $(p<0.05)$ were considered to have significant effect on xylanase production from the regression analysis of variables.

\section{Central composite design, response surface methodology and statistical analysis}

Significant factors that contribute in xylanase production were further optimized by RSM using Minitab 15.1 (Bocchini et al., 2002; Wejse et al., 2003). Two level full factorial central composite design with 4 star points $(\alpha=1.41421)$ and a centre point with one 
Table 2: Plackett-Burman design showing six variables with coded values along with the observed results for xylanase production.

\begin{tabular}{|c|c|c|c|c|c|c|c|}
\hline $\begin{array}{l}\text { Run } \\
\text { Order }\end{array}$ & $\begin{array}{c}\mathrm{K}_{2} \mathrm{HPO}_{4} \\
(\mathrm{~g} / \mathrm{L})\end{array}$ & $\mathrm{NaCl}(\mathrm{g} / \mathrm{L})$ & $\begin{array}{c}\mathrm{MgSO}_{4} \cdot 7 \mathrm{H}_{2} \mathrm{O} \\
(\mathrm{g} / \mathrm{L})\end{array}$ & $\mathrm{CaCl}_{2}(\mathrm{~g} / \mathrm{L})$ & $\mathrm{Na}_{2} \mathrm{CO}_{3}(\mathrm{~g} / \mathrm{L})$ & $\begin{array}{l}\text { Rice husk } \\
\text { (g) }\end{array}$ & $\begin{array}{c}\text { Xylanase } \\
\text { activity } \\
\text { (IU/mL) }\end{array}$ \\
\hline 1 & 10(1) & 10(1) & $1(1)$ & $0.10(-1)$ & $20(1)$ & $5(-1)$ & 2.13 \\
\hline 2 & $10(1)$ & $10(1)$ & 1(1) & 1(1) & $20(1)$ & $20(1)$ & 9.37 \\
\hline 3 & $4(-1)$ & $4(-1)$ & $0.10(-1)$ & $1(1)$ & $6(-1)$ & $20(1)$ & 4.04 \\
\hline 4 & $10(1)$ & $10(1)$ & $1(1)$ & $1(1)$ & $6(-1)$ & $5(-1)$ & 4.18 \\
\hline 5 & $4(-1)$ & 10 & $0.10(-1)$ & 1 & $6(-1)$ & $5(-1)$ & 2.08 \\
\hline 6 & $4(-1)$ & $10(1)$ & $0.10(-1)$ & 1(1) & $20(1)$ & $20(1)$ & 3.25 \\
\hline 7 & $10(1)$ & $10(1)$ & $0.10(-1)$ & 1(1) & $6(-1)$ & $20(1)$ & 8.23 \\
\hline 8 & $4(-1)$ & $4(-1)$ & $0.10(-1)$ & $0.10(-1)$ & $20(1)$ & $20(1)$ & 4.23 \\
\hline 9 & $4(-1)$ & 10(1) & 1(1) & $1(1)$ & $20(1)$ & $5(-1)$ & 2.00 \\
\hline 10 & $7(0)$ & $14.14(2.38)$ & $0.55(0)$ & $0.55(0)$ & $13(0)$ & $12.50(0)$ & 3.21 \\
\hline 11 & $10(1)$ & $4(-1)$ & $1(1)$ & $0.10(-1)$ & $6(-1)$ & $5(-1)$ & 4.07 \\
\hline 12 & $4(-1)$ & $10(1)$ & $1(1)$ & $1(1)$ & $6(-1)$ & $20(1)$ & 4.14 \\
\hline 13 & $\begin{array}{l}-0.14 \\
(-2.38)\end{array}$ & $7(0)$ & $0.55(0)$ & $0.55(0)$ & $13(0)$ & $12.50(0)$ & 1.86 \\
\hline 14 & $10(1)$ & $4-1)$ & $0.10(-1)$ & $0.10(-1)$ & $6(-1)$ & $20(1)$ & 8.98 \\
\hline 15 & $7(0)$ & $7(0)$ & $\begin{array}{l}-0.52 \\
(-2.38)\end{array}$ & $0.55(0)$ & $13(0)$ & $12.50(0)$ & 3.22 \\
\hline 16 & $10(1)$ & $4(-1)$ & $1(1)$ & $0.10(-1)$ & $20(1)$ & $20(1)$ & 9.61 \\
\hline 17 & $7(0)$ & $7(0)$ & $0.55(0)$ & $0.55(0)$ & $13(0)$ & $12.50(0)$ & 4.70 \\
\hline 18 & $7(0)$ & $7(0)$ & $0.55(0)$ & $1.62(-2.38)$ & $13(0)$ & $12.50(0)$ & 1.94 \\
\hline 19 & $4(-1)$ & $4(-1)$ & $1(1)$ & $0.10(-1)$ & $20(1)$ & $5(-1)$ & 1.76 \\
\hline 20 & $7(0)$ & $7(0)$ & $0.55(0)$ & $0.55(0)$ & $13(0)$ & $12.50(0)$ & 3.28 \\
\hline 21 & $4(-1)$ & $10(1)$ & $0.10(-1)$ & $0.10(-1)$ & $20(1)$ & $5(-1)$ & 10.34 \\
\hline 22 & $4(-1)$ & $10(1)$ & $1(1)$ & $0.10(-1)$ & $20(1)$ & $20(1)$ & 4.75 \\
\hline 23 & $10(1)$ & $10(1)$ & $0.10(-1)$ & $1(1)$ & $20(1)$ & $5(-1)$ & 4.30 \\
\hline 24 & $10(1)$ & $4(-1)$ & $0.10(-1)$ & $0.10(-1)$ & $20(1)$ & $5(-1)$ & 4.81 \\
\hline 25 & $7(0)$ & $7(0)$ & $0.55(0)$ & $\begin{array}{l}-0.52 \\
(-2.38)\end{array}$ & $13(0)$ & $12.50(0)$ & 1.94 \\
\hline 26 & $10(1)$ & $10(1)$ & $0.10(-1)$ & $0.10(-1)$ & $20(1)$ & $20(1)$ & 9.92 \\
\hline 27 & $4(-1)$ & $4(-1)$ & $1(1)$ & $1(1)$ & $20(1)$ & $20(1)$ & 4.82 \\
\hline 28 & $10(1)$ & $10(1)$ & $1(1)$ & $0.10(-1)$ & $6(-1)$ & 20(1) & 9.00 \\
\hline 29 & $7(0)$ & $7(0)$ & $0.55(0)$ & $0.55(0)$ & $13(0)$ & $\begin{array}{l}-5.34 \\
(-2.38)\end{array}$ & 1.86 \\
\hline 30 & $7(0)$ & $7(0)$ & $1.62(2.38)$ & $0.55(0)$ & $13(0)$ & $12.50(0)$ & 3.70 \\
\hline 31 & $7(0)$ & $7(0)$ & $0.55(0)$ & $0.55(0)$ & $13(0)$ & $12.50(0)$ & 3.27 \\
\hline 32 & $4(-1)$ & $4(-1)$ & $1(1)$ & $1(1)$ & $6(-1)$ & $5(-1)$ & 2.69 \\
\hline 33 & $7(0)$ & $7(0)$ & $0.55(0)$ & $0.55(0)$ & $13(0)$ & $12.50(0)$ & 2.99 \\
\hline 34 & $4(-1)$ & $4(-1)$ & $0.10(-1)$ & $1(1)$ & $20(1)$ & $5(-1)$ & 2.00 \\
\hline 35 & $14.14(2.38)$ & $7(0)$ & $0.55(0)$ & $0.55(0)$ & $13(0)$ & $12.50(0)$ & 5.07 \\
\hline 36 & $7(0)$ & $7(0)$ & $0.55(0)$ & $0.55(0)$ & $\begin{array}{l}-3.65 \\
(-2.38)\end{array}$ & $12.50(0)$ & 3.52 \\
\hline 37 & $7(0)$ & $-0.14(-2.38)$ & $0.55(0)$ & $0.55(0)$ & $13(0)$ & $12.50(0)$ & 3.70 \\
\hline 38 & $4(-1)$ & $4(-1)$ & $0.10(-1)$ & $0.10(-1)$ & $6(-1)$ & $5(-1)$ & 1.86 \\
\hline 39 & $10(1)$ & $4(-1)$ & $1(1)$ & $1(1)$ & $20(1)$ & $5(-1)$ & 4.12 \\
\hline 40 & $10(1)$ & 10(1) & $0.10(-1)$ & $0.10(-1)$ & $6(-1)$ & $5(-1)$ & 3.94 \\
\hline
\end{tabular}




\begin{tabular}{cccccccc}
\hline 41 & $7(0)$ & $7(0)$ & $0.55(0)$ & $0.55(0)$ & $13(0)$ & $12.50(0)$ & 3.13 \\
42 & $7(0)$ & $7(0)$ & $0.55(0)$ & $0.55(0)$ & $13(0)$ & $30.34(2.38)$ & 8.34 \\
43 & $10(1)$ & $4(-1)$ & $0.10(-1)$ & $1(1)$ & $6(-1)$ & $5(-1)$ & 4.33 \\
44 & $7(0)$ & $7(0)$ & $0.55(0)$ & $0.55(0)$ & $13(0)$ & $12.50(0)$ & 3.83 \\
45 & $7(0)$ & $7(0)$ & $0.55(0)$ & $0.55(0)$ & $13(0)$ & $12.50(0)$ & 3.62 \\
46 & $10(1)$ & $4(-1)$ & $1(1)$ & $1(1)$ & $6(-1)$ & $20(1)$ & 10.02 \\
47 & $7(0)$ & $7(0)$ & $0.55(0)$ & $0.55(0)$ & $29.65(2.38)$ & $12.50(0)$ & 5.21 \\
48 & $10(1)$ & $4(-1)$ & $0.10(1)$ & $1(1)$ & $20(1)$ & $20(1)$ & 9.84 \\
49 & $7(0)$ & $7(0)$ & $0.55(0)$ & $0.55(0)$ & $13(0)$ & $12.50(0)$ & 4.04 \\
50 & $7(0)$ & $7(0)$ & $0.55(0)$ & $0.55(0)$ & $13(0)$ & $12.50(0)$ & 4.12 \\
51 & $4(-1)$ & $10(1)$ & $1(1)$ & $0.10(-1)$ & $6(-1)$ & $5(-1)$ & 1.78 \\
52 & $4(-1)$ & $10(1)$ & $0.10(-1)$ & $0.10(-1)$ & $6(-1)$ & $20(1)$ & 7.18 \\
53 & $4(-1)$ & $4(-1)$ & $1(1)$ & $0.10(-1)$ & $6(-1)$ & $20(1)$ & 7.67 \\
\hline
\end{tabular}

Table 3: Full factorial central composite design matrix for two variables in five settings in real and coded units (parenthesis) and response of xylanase activity.

\begin{tabular}{cccccc}
\hline Run & $\mathrm{K}_{2} \mathrm{HPO}_{4}$ & \multirow{2}{*}{ Rice husk $(\mathrm{g})$} & \multicolumn{2}{c}{ Xylanase activity $(\mathrm{IU} / \mathrm{mL})$} & Residuals \\
\cline { 4 - 5 } Order & $(\mathrm{g} / \mathrm{L})$ & Observed & Predicted & \\
\hline 1 & $17.5(0)$ & $30(0)$ & 10.400 & 9.647 & 0.7540 \\
2 & $6.89(-1)$ & $30(-1)$ & 10.094 & 9.881 & 0.2130 \\
3 & $28.11(0)$ & $30(0)$ & 10.441 & 10.282 & 0.1590 \\
4 & $17.5(+1)$ & $30(-1)$ & 10.237 & 9.647 & 0.5900 \\
5 & $17.5(-1)$ & $30(+1)$ & 8.225 & 9.647 & -1.4220 \\
6 & $17.5(-2)$ & $44.14(0)$ & 10.278 & 9.600 & 0.6780 \\
7 & $25(0)$ & $20(+2)$ & 8.041 & 7.861 & 0.1800 \\
8 & $17.5(0)$ & $30(0)$ & 9.226 & 9.647 & -0.4210 \\
9 & $10(0)$ & $20(0)$ & 8.205 & 8.063 & 0.1420 \\
10 & $17.5(+1)$ & $30(+1)$ & 10.145 & 9.647 & 0.4980 \\
11 & $17.5(+2)$ & $15.66(0)$ & 6.183 & 6.487 & -0.3050 \\
12 & $25(0)$ & $40(-2)$ & 10.033 & 10.547 & -0.5150 \\
13 & $10(0)$ & $40(0)$ & 9.226 & 9.779 & -0.5530 \\
\hline
\end{tabular}

replication resulting in a total of 13 experiments were used to optimize the chosen key variables for xylanase productivity in SSF. All the experiments were done in triplicate and average of enzyme activity is reported in Table 3. Second-order polynomial equation was fitted to correlate the relationship between variables and response (xylanase activity) in order to predict optimal point (Kalogeris et al., 1998). The equation is:

$$
Y=\beta_{0}+\sum_{i=1}^{k} \beta_{i} X_{i}+\sum_{i=1}^{k} \beta_{i i} X_{i}+\sum_{i} \sum_{j} \beta_{i j} X_{i} X_{j}
$$

Where $Y$ is the predicted response, $k$ is the number of factor variables, $\beta_{0}$ is the model constant, $\beta_{i}$ is the linear coefficient, $\beta_{\mathrm{ii}}$ is the quadratic coefficient, $\beta_{\mathrm{ij}}$ is the interaction coefficient.

Minitab 15.1 was used to evaluate analysis of variance (ANOVA) to determine significance of each term in the equation fitted and to estimate goodness of fit in each case. Based on experimental results, response surface was drawn to show individual and cumulative effects of variables and the mutual interaction between them.

\section{Purification of enzyme}

Crude enzyme was precipitated using $80 \%$ saturation of Ammonium sulphate. The precipitate was dissolved in phosphate buffer $\mathrm{pH} 6.8$ and was dialysed. A column (50 $\mathrm{cm} \times 26.63 \mathrm{~mm}$ ) with Sephadex G-100 was saturated with phosphate buffer $\mathrm{pH}$ 6.8. Dialysed enzyme $(50 \mu \mathrm{L})$ and phosphate buffer $\mathrm{pH} 6.8(50 \mu \mathrm{L})$ were loaded in the column. The velocity of liquid movement in the column was maintained at $12 \mathrm{~mL} / \mathrm{h}$. Phosphate buffer $\mathrm{pH} 7.6$ was maintained above top surface of the Sephadex G-100 layer to prevent the column from becoming dry. Each four drops from the column was collected separately. Then eluted sample $(0.1 \mathrm{~mL})$ and xylan $(20 \mathrm{mg} / \mathrm{mL} ; 0.9 \mathrm{~mL})$ were incubated at $55^{\circ} \mathrm{C}$ for $30 \mathrm{~min}$. Xylanase activity was determined for crude enzyme, ammonium sulphate precipitation and elution through sephadex G-100 column by DNS method.

Purified enzyme was lyophilized and stored at $4-8{ }^{\circ} \mathrm{C}$ in refrigerator. Protein estimation of the enzyme was done by Lowry method (Lowry et al., 1951). 


\section{Partial Characterization of the enzymes}

Effect of $\mathrm{pH}$ on xylanase activity

To determine the optimum $\mathrm{pH}$ for enzyme activity, the samples were assayed at various $\mathrm{pH}$ viz. 4, 5, 6, 6.6, 7, 7.6, 8 and 9 by DNS method after exposing the samples for $10 \mathrm{~min}$ at $55^{\circ} \mathrm{C}$ (Kalogeris et al., 1998).

\section{Effect of temperature on xylanase activity}

To determine the optimum temperature for enzyme activity, the samples were assayed at various temperatures viz. $40,45,50,55,60,65,70,75$ and $80{ }^{\circ} \mathrm{C}$ by DNS method after exposing the samples for $10 \mathrm{~min}$ in phosphate buffer ( $\mathrm{pH} 7.6)$.

\section{Determination of thermal stability of the enzyme}

The crude enzyme $(1 \mathrm{~mL})$ was incubated at different temperature $\left(30,40,50,60,70,80,90\right.$ and $\left.100^{\circ} \mathrm{C}\right)$ for 10 min. Then xylan $(100 \mu \mathrm{L} ; 20 \mathrm{mg} / \mathrm{mL})$ was added to the crude enzyme samples and kept at $60{ }^{\circ} \mathrm{C}$ for $10 \mathrm{~min}$ Residual xylanase activity of each sample was measured by DNS method (Sa-Pereira, 2002; Xiong, 2004).

\section{RESULTS AND DISCUSSION}

\section{Identification of organism}

The isolate was sent to Institute of Microbial Technology, IMTECH, Chandigadh, India, for its identification. They have conducted taxonomic studies as well as 16S rRNA gene analysis (1393 bp).

On the basis of their taxonomic studies and 16s rRNA analysis, IMTECH identified it as Brevibacillus borstelensis. It was deposited in IMTECH with accession number MTCC 9874 . So far there are no reports on the production of xylanase from Brevibacillus borstelensis. This strain is important as it can produce thermophilic and alkali-tolerant xylanase.

\section{Enzymatic production}

Maximum xylanolytic activity among five medium after SSF for 96 hours was seen in MSS-1 (Table 4). Thus, this medium was chosen for medium and condition optimizations study.

Table 4: Xylanolytic activity Mineral salt solutions with different substrates (Rice husk, Rice straw and Wheat straw) after SSF of $96 \mathrm{~h}$.

\begin{tabular}{|c|c|c|c|c|c|}
\hline Medium & MSSRH1 & MSSRH2 & MSSRH3 & MSSRH4 & MSSRH5 \\
\hline $\begin{array}{l}\text { Xylanolytic } \\
\text { activity }\end{array}$ & -0.17885 & 1.521154 & 0.876923 & 0.175 & 1.275 \\
\hline Medium & MSSRS1 & MSSRS2 & MSSRS3 & MSSRS4 & MSSRS5 \\
\hline $\begin{array}{l}\text { Xylanolytic } \\
\text { activity }\end{array}$ & 10.38269 & 0.157692 & -0.26923 & 8.598077 & -0.33462 \\
\hline Medium & MSSWS1 & MSSWS2 & MSSWS3 & MSSWS4 & MSSWS5 \\
\hline $\begin{array}{l}\text { Xylanolytic } \\
\text { activity }\end{array}$ & 0.021154 & 0.509615 & 0.792308 & 1.478846 & 1.213462 \\
\hline
\end{tabular}

MSSRH: Mineral salt solution with Rice husk; MSSRS: Mineral salt solution with Rice straw and MSSWS: Mineral salt solution with wheat straw.

\section{Plackett-Burman Design}

The result of PBD showed that dipotassium hydrogen phosphate and rice husk were significant factors for xylanase production. Sodium chrloride, Magnesium sulphate, sodium carbonate and calcium chloride were found insignificant.
Therefore, the quantity of all the ingredients of medium which were insignificant in production of xylanase was kept constant in subsequent experiments. The model equation for xylanase production neglecting insignificant variables is as follows:

$\mathrm{Y}_{\text {activity }}=36.5+16 \mathrm{X}+32.4 \mathrm{Y}$ 
Where, $\mathrm{Y}_{\text {activity }}=$ Enzyme activity, $\mathrm{X}=\mathrm{K}_{2} \mathrm{HPO}_{4}$ and $\mathrm{Y}=$ Rice husk

\section{Central Composite Design and statistical analysis}

The result of enzyme activity when Brevibacillus borstelensis was incubated for 96 hours as per 13 experiment of CCD showed that maximum enzyme activity $(10.4 \mathrm{IU} / \mathrm{mL})$ was found in run 1 in which $17.5 \mathrm{~g} / \mathrm{L}$ and $30 \mathrm{~g}$ of $\mathrm{K}_{2} \mathrm{HPO}_{4}$ and rice husk were used respectively (Table 3).

Minitab 15.1 was used to find out quadratic mathematical model for uncoded values [Equation 4]:

$\mathrm{Y}_{\text {activity }}=1.68218-0.213301 \mathrm{X}+0.534309 \mathrm{Y}+$ $0.00386256 X^{2}-0.00801420 Y^{2}+0.00323393 X Y$
Where, $\mathrm{Y}_{\text {activity }}=$ Enzyme activity, $\mathrm{X}=\mathrm{K}_{2} \mathrm{HPO}_{4}$ and $\mathrm{Y}=$ Rice husk

The model (equation 4) did not show lack of fit $(p=$ 0.706 ) as shown in Table 6 . The model can explain $76.83 \%\left(R^{2}=76.83 \%\right)$ of the variation in xylanase activity and can predict $29.05 \%\left(R^{2}\right.$ predicted $=29.05 \%$ ) of the xylanase activity (Table 5$)$.

Response surface to estimate dependent variable, xylanase activity, over independent variables, $\mathrm{K}_{2} \mathrm{HPO}_{4}$ and Rice husk concentrations as per equation (4) is shown in Figure 1. The surface was curved in structure with the change in $\mathrm{K}_{2} \mathrm{HPO}_{4}$ concentration showing that $\mathrm{K}_{2} \mathrm{HPO}_{4}(25 \mathrm{~g} / \mathrm{L})$ is showing peak xylanase activity where as rice husk $(40 \mathrm{~g})$ has shown maximum xylanase activity. Contour plots obtained from Response surface methodology suggested optimized concentrations of xylan

Table 5: Results of regression analysis of the full factorial Central Composite Design (CCD).

\begin{tabular}{|c|c|c|c|c|}
\hline Term & Coefficient & SE Coefficient & T- statistics & $p$-value \\
\hline Constant & 9.6467 & 0.3629 & 26.5840 & 0 \\
\hline $\mathrm{K}_{2} \mathrm{HPO}_{4}(\mathrm{X})$ & 0.1418 & 0.2869 & 0.4940 & 0.6360 \\
\hline Rice husk (Y) & 1.1005 & 0.2869 & 3.836 & 0.0060 \\
\hline $\mathrm{K}_{2} \mathrm{HPO}_{4} \times \mathrm{K}_{2} \mathrm{HPO}_{4}\left(\mathrm{X}^{2}\right)$ & 0.2173 & 0.3076 & 0.706 & 0.5030 \\
\hline Rice husk $\times$ Rice husk $\left(\mathrm{Y}^{2}\right)$ & -0.8014 & 0.3076 & -2.605 & 0.035 \\
\hline $\mathrm{K}_{2} \mathrm{HPO}_{4} \times$ Rice husk & 0.2425 & 0.4057 & 0.5980 & 0.569 \\
\hline
\end{tabular}

Standard deviation of error term in the model, $S=0.811411$; Sum of squares of the prediction errors, PRESS $=14.1147 ; R^{2}=76.83 ; R^{2}$ $($ predicted $)=29.05 \% \& R^{2}($ adjusted $)=60.29 \%$

Table 6: Analysis of variance (ANOVA) for the model regression representing xylanase activity.

\begin{tabular}{lllllll}
\hline Source & DF & $\begin{array}{l}\text { Sequential } \\
\text { SS }\end{array}$ & $\begin{array}{l}\text { Adjusted } \\
\text { SS }\end{array}$ & $\begin{array}{l}\text { Adjusted } \\
\text { MS }\end{array}$ & F-ratio & p-value \\
\hline Regression & 5 & 15.2861 & 15.2861 & 3.0572 & 4.6400 & 0.0350 \\
Linear & 2 & 9.8499 & 9.8499 & 4.9250 & 7.4800 & 0.0180 \\
Square & 2 & 5.2009 & 5.2009 & 2.6004 & 3.9500 & 0.0710 \\
Interaction & 1 & 0.2353 & 0.2353 & 0.2353 & 0.3600 & 0.5690 \\
Residual error & 7 & 4.6087 & 4.6087 & 4.6087 & & 0.7060 \\
Lack of fit & 3 & 1.2460 & 1.2460 & 0.4153 & 0.4900 & \\
Pure error & 4 & 3.3627 & 3.3627 & 0.8407 & & \\
Total & 12 & 19.8948 & & & & \\
\hline
\end{tabular}

Where, DF: Degree of freedom; SS: Sum of square; MS: Mean square

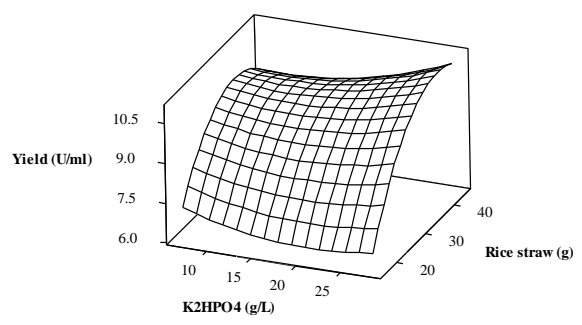

Figure 1: Response surface described by equation 4 which represents xylanase activity $(\mathrm{IU} / \mathrm{mL})$ as a function of $\mathrm{K}_{2} \mathrm{HPO}_{4}$ and rice husk concentration). 


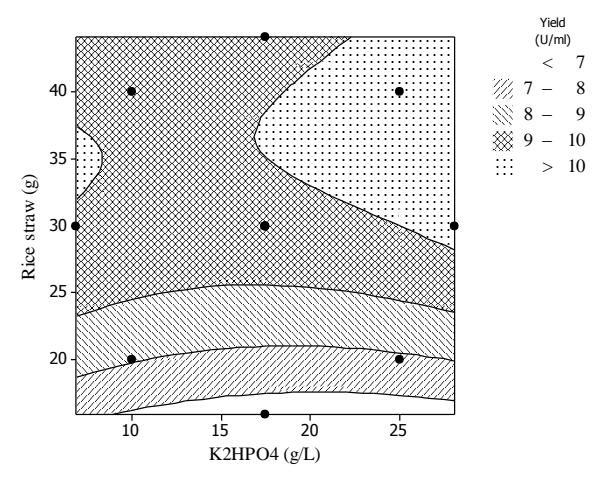

Figure 2: Contour plot of xylanolytic activity (IU/mL) vs. $\mathrm{K}_{2} \mathrm{HPO}_{4}(\mathrm{~g} / \mathrm{L})$ and rice husk (g).

(25 g/L) while rice husk (40 g) (Figure 2). There was $279.88 \%$ increase in xylanolytic activity after optimization of the medium.

\section{Purification of enzyme}

Crude enzyme (500 mL) obtained from fermentation followed by centrifugation $\left(-10^{\circ} \mathrm{C}, 10,000 \mathrm{rpm}\right)$ for $10 \mathrm{~min}$, was subjected to xylanolytic activity as described earlier. Crude enzyme $(500 \mathrm{~mL})$ was $80 \%$ saturated with ammonium sulphate and precipitates were dissolved in $400 \mathrm{~mL}$ of phosphate buffer $\mathrm{pH}$ 7.6. Xylanolytic activity of ammonium sulphate precipitation was measured. Similarly, dialyzed enzyme $(0.5 \mu \mathrm{L})$ and phosphate buffer $\mathrm{pH} 7.6(0.5 \mu \mathrm{L})$ were loaded in phosphate buffer $\mathrm{pH} 7.6$ saturated sephadex $\mathrm{G}-100$ column $(50 \mathrm{~cm} \times 26.63 \mathrm{~mm})$. Sample number 18 to 22 showed xylanolytic activity. The samples were mixed and xylanolytic activity of the mixture was measured and showed in Table 7 . Other parameters such as total activity, protein, specific activity, yield and purification fold of the enzyme were determined after each step of purification (Table 7).

\section{Kinetic Study}

The enzyme kinetics was studied at optimum $\mathrm{pH}(\mathrm{pH} 7.6)$ and temperature $\left(60^{\circ} \mathrm{C}\right)$ and the results of Michaelis Menten and Lineweaver-Burk plots are shown in Figures 4 and 5 respectively.

Initial reaction rates were determined at different substrate (xylan from birchwood) concentration ranged from 10 to $90 \mathrm{mg} / \mathrm{mL}$. Reaction rate (xylanolytic activity) vs. xylan concentration showed that the enzyme is obeying Michaelis-Menten kinetics. For the determination of $\mathrm{V}_{\max }$ and $\mathrm{K}_{\mathrm{m}}$ values, the Lineweaver-Burk plot was plotted between the reciprocal values of $\mathrm{S}$ and $\mathrm{V}$ (Bakir et al., 2001). Lineweaver - Burk plot gave $V_{\max }$ and $K_{m}$ values of $0.1075 \mu \mathrm{g} / \mathrm{mL}$.min and $1427.63 \mu \mathrm{g} / \mathrm{mL}$ respectively (Figure 4).

Table 7: Summary of purification of xylanase

\begin{tabular}{|c|c|c|c|c|c|c|c|}
\hline $\begin{array}{l}\text { State of } \\
\text { enzyme }\end{array}$ & $\begin{array}{c}\text { Xylanolytic } \\
\text { activity } \\
(\mu \mathrm{g} / \mathrm{mL} \times \min )\end{array}$ & $\begin{array}{c}\text { Total } \\
\text { activity } \\
\text { ( } \mu \mathrm{g} / \mathrm{min})\end{array}$ & $\begin{array}{l}\text { Protein } \\
\text { Conc } \\
(\mu \mathrm{g} / \mathrm{mL})\end{array}$ & $\begin{array}{l}\text { Total } \\
\text { protein } \\
(\mu \mathrm{g})\end{array}$ & $\begin{array}{l}\text { Yield } \\
(\%)\end{array}$ & $\begin{array}{c}\text { Specific } \\
\text { activity(Total } \\
\text { activity/Total } \\
\text { protein) }\end{array}$ & $\begin{array}{l}\text { Purification } \\
\text { fold }\end{array}$ \\
\hline Crude & 10 & 500 & 71.28 & 3564 & 100 & 0.14 & 1 \\
\hline $\begin{array}{l}\text { Ammonium } \\
\text { sulphate } \\
\text { precipitation }\end{array}$ & 14 & 420 & 62.12 & 1863.6 & 84 & 0.23 & 1.4 \\
\hline Elution through & & & 43.96 & & & & \\
\hline $\begin{array}{l}\text { Sephadex G- } \\
100 \text { column }\end{array}$ & 797.54 & 159.51 & & 8.79 & 31.9 & 18.15 & 79.75 \\
\hline
\end{tabular}

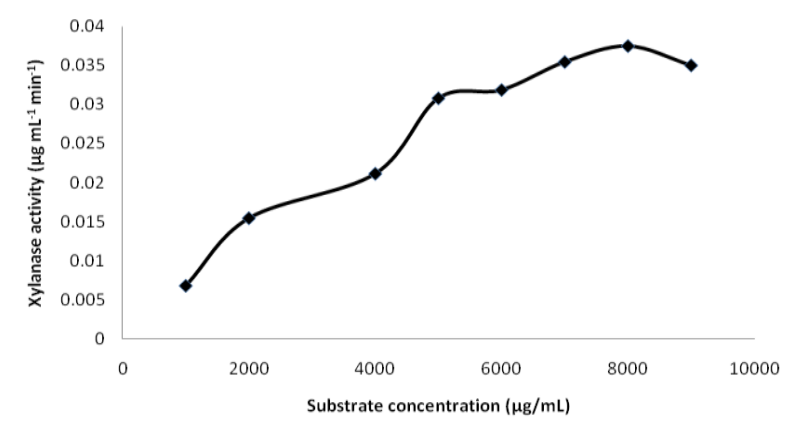

$\rightarrow-x y l a n a s e a c t i v i t y(\mu \mathrm{g} / \mathrm{m} \mid \times m i n)$

Figure 3: Substrate concentration vs. Xylanase activity to confirm that data is following saturated kinetics.

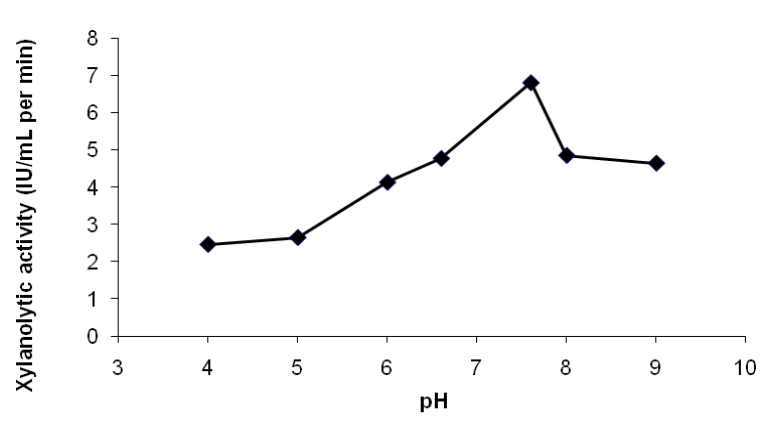

$\rightarrow$ IU/min

Figure 4: $\mathrm{pH}$ vs. xylanolytic activity for determination of optimum $\mathrm{pH}$ for maximum xylanolytic activity. 


\section{Effect of pH}

The effect of $\mathrm{pH}$ on enzyme activity was in the $\mathrm{pH}$ range of 6.6 to 8 and the results depicted in Figure 4. The figure clearly showed that maximum xylanolytic activity was observed at $\mathrm{pH}$ 7.6. Reasonably good enzymatic activity was observed in the alkaline range (7.6 to 9) indicating that it is an alkalophilic enzyme though $\mathrm{pH}$ greater than 10 can be encountered during kraft pulp bleaching (Morris, 1997).

\section{Effect of temperature}

The results indicated that maximum xylanolytic activity was observed at $60{ }^{\circ} \mathrm{C}(6.58 \pm 1.1 \mathrm{IU} / \mathrm{mL})$. Good enzyme activity was observed from 50 to $70^{\circ} \mathrm{C}$. Thus, it suggests that the enzyme is the most suitable for pulp and paper industries as it has optimum activity at $60^{\circ} \mathrm{C}$ (Figure 5).

\section{Thermal stability of the enzyme}

The crude xylanase samples were incubated at 40,50 , 60,70 and $80{ }^{\circ} \mathrm{C}$ for a period of $10 \mathrm{~min}$ at optimum $\mathrm{pH}$ and their residual activities were estimated. The result indicated that the enzyme was relatively stable in between 25 and $60{ }^{\circ} \mathrm{C}$ (Figure 6). But at 40, 50, 60, 70 and $80{ }^{\circ} \mathrm{C}$, about $0,8,1.68,4.38,53.1$ and $67.24 \%$ of original activity were lost respectively. Thermal stability study indicated that the enzyme has a good stability upto $60{ }^{\circ} \mathrm{C}(95.62 \%)$ in comparison with initial xylanolytic activity. Xylanolytic activity was found to be decreasing when temperature was increased beyond $60{ }^{\circ} \mathrm{C}$ (Figure 6). It showed that this xylanase is thermostable in comparison with other xylanases found in literature (Ratto et al., 1992; Wang et al., 2003).

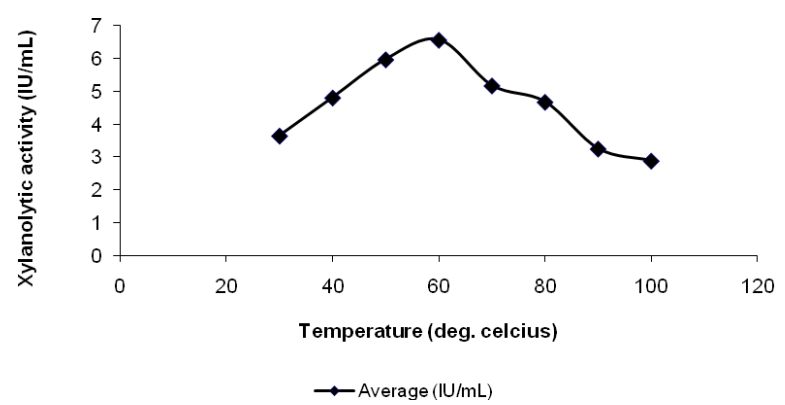

Figure 5: Temperature vs. xylanolytic activity for determination of optimum temperature for maximum xylanolytic activity.

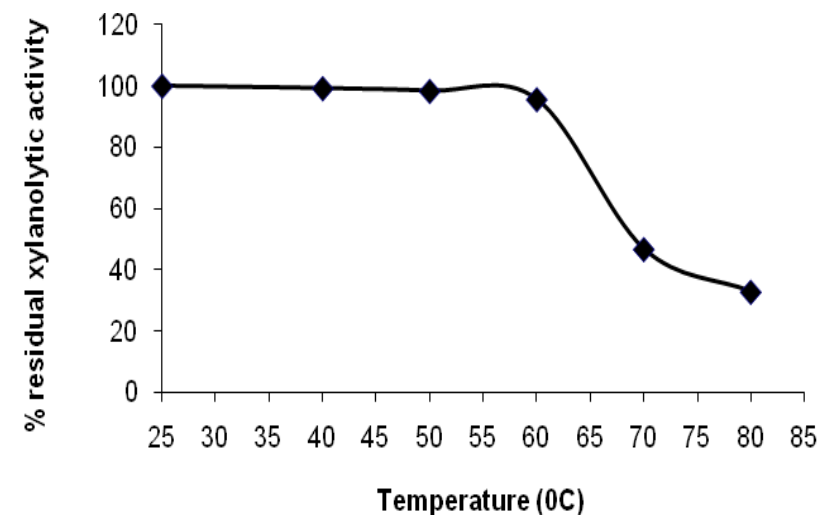

Figure 6: Thermostability study of xylanase.

\section{CONCLUSION}

So far there are no reports on the production of xylanase from Brevibacillus borstelensis. In the present investigation, we isolated a novel strain of thermophilic $B$. borstelensis which is producing thermostable and alkalitolerant xylanase. Xylanase was produced by our new isolate $B$. borstelensis and purified. As the enzyme is thermostable and alkali-tolerant, it has a potential application in the industrial processes where high temperature and high $\mathrm{pH}$ environments are existed during processing.

\section{ACKNOWLEDGEMENTS}

The authors would like to acknowledge International Federation for Science (IFS), Sweden and Organisation for the Prohibition of Chemical Weapons (OPCW), The Hague, The Netherlands for the research grant for the study. I would also like to thank Prof. Prabhakar Reddy Veerareddy for his help to characterize the isolated organism.

\section{REFERENCES}

Armstrong, N. A. (2006). Pharmaceutical Experimental Design and Interpretation. CRC Taylor and Francis. Boca Raton. pp. 121-150.

Asha Poorna, C. and Prema P. (2007). Production of cellulase-free endoxylanase from novel alkalophilic thermotolerent Bacillus pumilus by solid-state fermentation and its application in wastepaper recycling. Bioresource Technology 98, 485-490.

Bakir, U., Yavascaoglu, S., Guvenc, F. and Ersayin, A. (2001). An eno- $\beta-1,4-x y l a n a s e$ from Rhizopus oryzae: Production, partial purification and biochemical characterization. Enzyme and Microbial Technology 29, 328-334.

Bocchini, D.A., Alves-Prado, H.F., Baida, L.C, Roberto, I.C., Gomes, E. and Da Silva, R. (2002). Optimization of xylanase production by Bacillus circulans D1 in submerged fermentation using 
response surface methodology. Process Biochemistry 38, 727-731.

Cordeiro, C. A. M., Martins, M. L. L., Luciano, A. B. and Da Silva, R. F. (2002). Production and properties of xylanase from thermophilic Bacillus sp. Brazilian Archives of Biology and Technology 45(4), 413418.

Ghanem, N. B., Yusef, H. H. and Mahrouse, H. K. (2000). Production of Aspergillus terreus xylanase in solid-state cultures: application of the PlackettBurman experimental design to evaluate nutritional requirements. Bioresource Technology 73, 113121.

Kalogeris, E., Christakopoulos, P., Kekos, D. and Macris, B. J. (1998). Studies on the solid-state production of thermostable endoxylanases from Thermoascus aurantiacus: characterization of two isozymes. Journal of Biotechnology 60,155-163.

Kalogeris, E., Christakopoulos, P., Vrsansca, M., Kekos, D., Biely, P. and Macris B. J. (2000). Catalytic properties of the endoxylanase I from Thermoascus aurantiacus. Journal of Molecular Catalysis B: Enzymatic 11, 491-501.

Kuhad, R. C., Manchanda, M. and Singh, A. (1998). Optimization of xylanase production by a hyperxylanolytic mutant strain of Fusarium oxyporum. Process Biochemistry 33(6), 641-647.

Lowry, O.H., Rosebrough, N.J., Farr A.L. and Randall R.J. (1951). Protein measurement with the Folin phenol reagent. The Journal of Biological Chemistry 193(1):265-75.

Miller, G. L. (1959). Use of dinitrosalicylic acid reagent for determination of reducing sugar. Analytical Chemistry 31(3), 426-428.

Morris, D. D. (1997). Isolation of xylanase genes from extremely thermophilic bacteria as potential Kraft Pulp Bleaching Aids. PhD Thesis, The University of Auckland, New Zealand.

Nascimento, R. P. Coelho, R. R. R., Marques, S., Arlves, L., Girio, F. M., Bon, E. P. S. and Amaral Collaco, M. T. (2002). Production and partial characterization of xylanase from Streptomyces sp. Strain AMT- 3 isolated from Brazilian cerrado soil. Enzyme and Microbial Technology 31, 549-555.

Ratto, M., Poutanen, K. and Vikari, L. (1992). Production of xylanolytic enzymes by an alkalitolerant Bacillus circulans strain. Applied Microbiology and Biotechnology 37, 470-473.

Ryan, S. E., Nolan, K., Thompson, R., Gubitz, G. M., Savage, A. V. and Tuohy, M. G. (2003). Purification and characterization of a new low molecular weight endoxylanase from Penicillium capsulatum. Enzyme and Microbial Technology 33, 775-785.

Sa-Pereira, P., Costa-Ferreira, M. and Aires-Barros, M. R. (2002). Enzymatic properties of a neutral endo1,3(4)- $\beta$-xylanase Xyl II from Bacillus subtilis. Journal of Biotechnology 94, 265-275.
Virupakshi, S., Gireesh, B. K., Satish, R. G. and Naik, G. R. (2005). Production of a xylanolytic enzyme by a thermoalkaliphilic Bacillus sp. JB-99 in solid state fermentation. Process Biochemistry 40, 431-435.

Wang, S. L., Yen, Y., Shih, I., Chang, A. C., Chang, W., Wu, W. and Chai Y. (2003). Production of xylanases from rice bran by Streptomyces actuosus A-151. Enzyme and Microbial Technology $33,917-925$.

Wejse, P. L., Ingvorsen, K. and Mortensen, K. K. (2003). Xylanase production by a novel halophilic bacterium increased 20 -fold by response surface methodology. Enzyme and Microbial Technology 32, 721-727.

Xiong, H., Nyyssölä, A., Jänis, J., Pastinen, O., Weymarn, N., Leisola, M. and Turunen, O. (2004). Characterization of the xylanase produced by submerged cultivation of Thermomyces lanuginosus DSM 10635. Enzyme and Microbial Technology 35, 93-99. 